\title{
MENEROPONG KONDISI PERUSAHAN DALAM PROSPEK PENGEMBANGAN INVESTASI
}

\author{
oleh: \\ *) Hamdi Sari Maryoni \\ *) Ikhsan Gunawan \\ *) Yuli Rahmini Suci \\ *) Dosen Universitas Pasir Pangairan
}

\begin{abstract}
Ringkasan
Artikel ini hanya mendeskripsikan pengunaan analisis fundamental dalam tindakan berivestasi. Analisis rasio fundamental merupakan alat untuk menggambarkan hubungan matematis antara satu item dengan item yang lain yang biasanya dinyatakan dalam persentase dan mengungkapkan hubungan penting yang menjadi dasar perbandingan dalam menemukan kondisi dan tren yang sulit untuk dideteksi dengan mempelajari masing-masing komponen yang membentuk rasio. Ada 4 jenis rasio yang biasa dipergunakan; rasio aktivitas, rasio likuiditas, rasio solvabilitas,rasio profitabilitas. Sehingga, investor lebih cermat dalam menganalisis investasi dalam mengambil keputusan berinvestasi untuk mengahadapi resiko yang akan muncul.
\end{abstract}

Kata kunci: Analisis, fundamental, rasio dan resiko.

\section{Pendahuluan}

Perekonomian Indonesia diprediksi akan semakin baik dan tren akan terus berkembang meningkat bila dikelola dengan lebih baik, sebab bila tidak disikapi dengan penuh ketelitian dan kehati-hatian akan menyulitkan bahkan dapat menurunkan prospek ekonomi Indonesia dimasa depan. Tantangan yang dihadapi tidak hanya datangnya dari luar tetapi juga dari dalam yang bila tidak segara dibendungan dan ditemukan solusinya maka barang tentu akan menghambat pertumbuhan ekonomi yang telah dibangun dan akan merusak tantanan semua sektor pendukung ekonomi Indonesia. Sehingga, dampak tidak hanya akan dirasakan dalam jangka pendek tetapi bisa berpengaruh kepada jangka panjang perekonomian bangsa ini.

Prediksi ekonomi ada empat tantangan global yang sangat berkaitan satu dan yang lainya. Tantangan ini, mempengaruhi pertumbuhan ekonomi domestik dan khususnya pengembangan investasi perusahan-perusahaan yang ada. Pertama, pemulihan pertumbuhan ekonomi dan volume perdagangan global berisiko tidak sekuat perkiraan, yang kemudian dapat berdampak pada harga komoditas yang tidak setinggi proyeksi. Kedua, kebijakan perdagangan internasional di negara maju yang menjadi lebih protektif. Risiko kedua ini dapat kembali menurunkan volume perdagangan dunia, pertumbuhan ekonomi global, dan harga komoditas. Ketiga, kombinasi kebijakan makroekonomi AS terutama kebijakan fiskal yang ekspansif dan kebijakan moneter yang lebih ketat yang dapat meningkatkan risiko pembalikan modal ke AS dan ketidakpastian pasar keuangan dunia. Keempat, inflasi global yang kembali naik bila harga 
komoditas dunia terus meningkat.Sehingga, harus ada ide yang cermerlang yang dikeluarkan pemerintah dalam menjawab tantangan perekonomian tersebut terkait dengan upaya memperkuat struktur perekonomian menjadi lebih berdaya saing dan tangguh disemua sektor.

Selanjutnya, kondisi diatas terkait tantangan dalam upaya memperkuat struktur perekonomian dari sektor riil dan sektor keuangan sebagai urat nadi perekonomian domestik. Tantangan struktural di sektor riil berhubungan dengan upaya untuk memperluas keragaman komposisi produk ekspor sehingga melengkapi peran ekspor produk sumber daya alam. Tantangan di sektor riil juga berhubungan dengan upaya meningkatkan peran industri pengolahan dalam perekonomian, dan memperkuat struktur pasar dan tata niaga sehingga lebih efisien.

Tantangan di sektor keuangan berkenaan dengan upaya untuk memperkuat struktur pembiayaan domestik sehingga menjadi lebih beragam, meningkatkan struktur dana perbankan sehingga menjadi lebih seimbang, serta memperdalam pasar keuangan sehingga dapat mendukung pembiayaan ekonomi dan meningkatkan efektivitas kebijakan moneter.

Kebijakan ini diarahkan untuk saling bersinegri antara Pemerintah, Bank Indonesia, dan Otoritas Jasa Keuangan. Sinergi kebijakan ditujukan untuk memitigasi risiko siklus jangka pendek guna tetap menjaga momentum pemulihan ekonomi. Momentum inilah yang dijadikan tolak ukur oleh para investor yang ingin ikut serta menyemarakan investasinya di Indonesia (Laporan Perekonomian BI, 2016:227).

Semua investasi berkaitan dengan resiko yang dihadapi. Semakin tinggi resiko yang dihadapi maka return yang diproleh akan semakin tinggi. Ini merupakan suatu mata uang yang saling berkaitan. Kelihainya seorang investor atau manajer dalam membaca peluang sangat di uji disini. Sehingga, fenomena seperti ini memaksa seorang investor atau manajer harus lebih kreatif dan hati-hati dalam mengelola sebuah investasi atau perusahaan untuk meraup profit.

Kondisi yang tersajikan diatas merupakan fenomena yang menarik untuk dicermati. Ada empat kondisi global yang mendasari dan mempengaruhi perekonomian domestik selain kebijakan pemerintah yang saling bersinegri untuk mendukung atau melindungi perekonomia. Ini artinya bahwa pemerintah berusaha menstimulu untuk mengersakan perekonomian menjadi lebih maju dan berkembang pesat. Mulai dari sektor riil dan keungan diupayakan oleh "Pemerintah" menjadi lebih baik atau berdaya saing demi menarik para investor untuk datang mencicipi manisnya investasi domestik.

Pasar Modal merupakan salah satu intrumen yang diciptakan oleh pemerintah untuk menarik para investor datang. Pasar modal banyak menawarkan berbagai macam investasi dari mulai obligasi, ekuiti, reksadana, instrumen derivatif hingga intrumen lainya. Menilik sebentar secara sederhana investasi merupakan sebuah kegiatan menempatkan dana pada suatu atau lebih dari 
suatu asset dalam jangka waktu tertentu dengan harapan dapat memperoleh profit atau keuntungan peningkatan nilai investasi. Investasi bisa diartikan sebagai penundaan konsumsi pada saat ini dengan tujuan memperoleh return yang lebih baik dimasa yang akan datang (Indah Pertiwi, 2014:2).

Sehingga, menarik untuk ditentukan bagaimana keputusan investasi harus dinilai dalam hubungan dengan kemampuan untuk menghasilkan keuntungan yang sama atau lebih besar yang disyaraktan oleh inverstor atau pemilik modal. Sebab, semua investasi selalu berkaitan dengan resiko yang dihadapi sehingga harus memiliki acuan dalam menentukan arah investasinya benar-benar menguntungkan (R.Agus Sartono, 2010:189-190). Hal ini harus diteropong dengan alat analisis yang tepat baik secara fundamental maupun teoritis. "Meneropong kondisi perusahan dalam prospek pengembangan investasi merupakan suatu hal yang menarik untuk lebih jauh diteliti. Penelitian ini bertujuan untuk memberikan gambaran pengetahuan dibidang menajemen investasi untuk lebih tepat dalam hal memutuskan investasi yang tepat dalam melokasikan investasi baik untuk mengendalikan resiko.

\section{Landasan Teori}

\section{Pasar Modal}

Pasar modal merupakan bagian dari pasar keuangan yang berfungsi untuk menyalaurkan dana dari pihak yang memiliki kelebihan dana dan menyalurkan kepada pihak yang membutuhkan investasi dana. Pihak yang memerlukan dana diwakili oleh perusahaan yang mengunakan pasar modal sebagai tempat transaksi pertukaran informasi dalam proses penghimpunan dana. Kegiatan perhimpunan dana tersebut dilakukan dengan cara menerbitkan surat berupa saham, obligasi, dan intrumen lainnya. Selanjutnya, pihak yang memiliki kelebihan dana atau investor dalam hal ini pemilik modal akan memiliki berbagai pilihan investasi sesuai dengan preferensi masing-masing.

Instrument pasar modal dipilih dalam kegiatan penghimpunan dana dan tempat investasi selain perbankan mulai populer di Indonesia. Keuntungan yang diperoleh dibandingkan dengan berinvestasi di sektor perbankan adalah perusahaan tidak memerlkan agunan seperti yang diisyaratkan jika melakukan pinjaman di sektor perbankan. Tetapi perusahan harus menunjukan performen terbaik sehingga investasi yang ditawarkan kepada para investor bisa laku terjual. Dalam investasi, investor rasional untuk mempertimbangkan melakukan transaksi jual beli saham atau obligasi, maka oleh sebab sebuah perusahan yang bertransaksi di bursa harus memberikan informasi detail dan terperinci sebagai pertimbanan para investor (Anditiya Soeroso, 2013:1687-1696). 
Menurut difenisi Irsan (2004:10) dalam Nasution (2015:96), bahwa "Pasar Modal" merupakan tempat kegiatan atau transaksi jual beli berbagai intrumen keuangan/sekuritas jangka panjang baik dalam bentuk utang maupun modal sendiri yang diterbitkan oleh perusahaan swasta. Selanjutnya diperjelas kembali oleh Sholihin (2010:351) dalam Nasution (2015:96), bahwa pasar modal adalah tempat transaksi perdagangan yang menawarkan surat berharga atau efek yang diterbitkan oleh lembaga efek yang memiliki kewengan tertentu.

Sedangkan dalam UU No.8 Tahun 1995 menjabarkan bahwa Pasar Modal adalah kegiatan yang bersangkutan dengan penawaran umum dan perdagangan efek, perusahan public yang berkaitan dengan efek yang diterbitkanya, serta lembaga dan profesi yang berkaitan dengan efek. Pengertian efek disini adalah surat pengakuan utang, surat berharga komersial, saham, obligasi, tanda bukti utang, unti penyertaan kontak kolektif, kontrak perpanjangan atas efek, dan setiap derevatif dari efek.

Sehingga, jelaslah bahwa "Pasar Modal" merupakan tempat menghimpun capital atau modal bagi perusahaan yang telah gopublic yang memiliki perfomer yang baik dan setiap investor bebas memilih investasinya. Investor harus memiliki ketelitian dalam meletakan investasinya di bursa efek sebab jika salah memilih efek maka akan berakibat resiko kerugian yang dialami.

Selanjutnya, untuk mengendalikan resiko maka seorang investor atau perusahan investasi harus memiliki keahlian atau analisis yang mumpuni dalam membaca kondisi pasar dalam melihat sebuah efek yang menguntungkan atau mendatangkan profit yang tinggi. Analisis tersebut diantaranya ada fundamental dan teknikal.

\section{Analisis Fundamental}

Analisis fundamental adalah studi tentang ekonomi, industry, dan kondisi perusahaan untuk memperhitungkan nilai dari saham perusahaan. Data-data perusahaan berupa laporan keungan perusahaan yang dijadikan acuan dalam menghitung apakah harga efek atau saham sudah terapresiasikan secara akurat dan informasi ini merupakan gambaran perusahaan tersebut dalam jangka tertentu menurut definisi Artha, dkk (2014:175-184).

Selanjutnya menurut definisi Fajar Fuady (2014:16), bahwa analisis fundamental adalah proses analisis skuritas dengan memperhatikan berbagai faktor baik internal (data-data keuangan perusahaan) maupun informasi eksternal perusahaan (sektor industri serta kondisi ekonomi secara makro) dengan tujuan untuk menentukan nilai intrinsik perusahaan.

Sehingga bisa diartinya secara luas bahwa analisis fundamental lebih fokusk pada potre yang tersajikan dalam laporan keuangan perusahaan yang bertujuan untuk mendeteksi perbedaan harga saham sekuritas dengan nilai intrinsiknya. Pendekatan fundamental memberikan dasar 
teoritis perhitungan nilai intrinsik yang dapat ditentukan berdasarkan faktor fundamental perusahaan misalnya laba, deviden, struktur modal, ratio dan potensi pertumbuhan perusahaan. studi tentang ekonomi dalam melakukan penilaian saham dengan mempelajari ataupun mengamati indikator yang timbul di ekonomi makro dan kondisi perusahaan termasuk berbagai indikator keuangan dan manajemen perusahaan.

Dengan demikian analisis fundamental merupakan analisis yang berbasis pada data riil yang dapat digunakan untuk mengevaluasi dan memproyeksikan nilai suatu saham. Penelitian ini mengukur analisis fundamental untuk pengaruhnya terhadap harga saham maka rasio yang akan digunakan adalah rasio likuiditas, leverage, profitabilitas, earning ratio (dalam Winosa, 2015:1).

Secara garis besar maka bisa ditarik benar merah bahwa analisis fundamental adalah analisis dalam melihat kinerja saham ada berbagai macam rasio yang bisa digunakan dan data keuangan atau laporan keuangan perusahaan sebagai gambaran potret kondisi perusahaan tersebut.

\section{Jenis-jenis Analisis Rasio Fundamental}

Analisis rasio fundamental merupakan alat untuk menggambarkan hubungan matematis antara satu item dengan item yang lain yang biasanya dinyatakan dalam persentase dan mengungkapkan hubungan penting yang menjadi dasar perbandingan dalam menemukan kondisi dan tren yang sulit untuk di deteksi dengan mempelajari masing-masing komponen yang membentuk rasio. Ada 4 jenis rasio yang biasa dipergunakan dalam analisis ini, diantaranya;

1. Rasio Aktivitas, digunakan untuk mengevaluasi pendapatan dan pengeluaran yang dihasilkan oleh aset-aset yang dimiliki perusahaan. Rasio ini mengukur seberapa efektif perusahaan memanfaatkan sumber daya yang ada pada pengendaliannya, atau digunakan untuk menilai efisiensi pengelolaan aktiva dalam menghasilkan pendapatan. Rasio ini terdiri dari;Priode Pengumpulan Piutang, Perputaran Piutang, Perputaran persediaan, Perputaran aktiva tetap, dan Perputaran Total Aktiva.

2. Rasio likuiditas adalah rasio mengukur kecukupan sumber kas perusahaan untuk memenuhi kewajiban-kewajiban kas jangka pendek serta untuk memenuhi kebutuhan kas yang tidak terduga. Selanjutnya, rasio ini juga terdiri dari; Current Ratio, dan Acid Test Ratio.

3. Rasio solvabilitas adalah rasio untuk mengukur kemampuan perusahaan dalam memenuhi kewajiban jangka panjangnya, yang terdiri dari analisis struktur modal perusahaan serta analisis mengenai kemampuan perusahaan dalam memenuhi 
pembayaran beban yang sifatnya tetap yaitu bunga. Rasio ini terdiri dari; Long Term Debt to Equity, dan Times Interest Earned

4. Rasio profitabilitas adalah untuk mengukur pendapatan perusahaan sehubungan dengan laba dan modal yang diinvestasikan dalam mendukung tingkat keberhasilan kegiatan operasi perusahaan dalam menghasilkan laba. Rasio ini terdiri dari; Gross Profit Margin, Operating Profit Margin, Net Profit Margin, Return on Asset, dan Return on Equity (White, Sandhi, dan Pride dalam Hauwtan, 2010:18-22 dan R.Agus Sartono,2010:113-138).

Sehingga, dengan mengunakan rasio tersebut investor dapat memilih perusahaan yang layak untuk dijadikan alternative investasi, memilih saham perusahaan yang harga pasarnya lebih rendah dari nilai intreristiknya sehingga layak dibeli, dan memilih saham perusahaan yang harga pasarnya lebih tinggi dari nilai intrisiknya sehingga menguntungkan untuk dijual (Eduardus Tandelilin, dalam Soepardi,.dkk,2007:3).

\section{Analisis Teknikal}

Analisis teknikal dilakukan dengan menggunakan grafik yang menjelaskan pergerakan harga dan volume pada masa yang lampau untuk meramalkan pergerakan harga pada masa yang akan datang. Periode atau waktu yang pas bagi analisis teknikal adalah jangka pendek sampai jangka panjang (Hauwtan, 2010:28).

\section{Metodologi}

Penelitian ini termasuk jenis penelitian studi literatur dengan mencari refrensi teori yang relefan dengan kasus atau permasalah yang terjadi dan ditemukan berkaitan dengan kondisi seorang investor atau perusahaab dalam mengembangkan bisnis untuk memproleh profit yang lebih baik. Refrensi teori yang diproleh dengan jalan penelitian studi literature dijadikan fondasi dasar dan alat utama bagi praktek penelitian selanjutnya. Jenis data yang digunakan dan dikembangkan adalah data skunder yang bisa di akses melalui Bursa Efek Indonesia dan data laporan keuangan yang terkait dengan penelitian yang akan dijalankan.

\section{Pembahasan}

Beberapa penelitian mengambarkan begitu pentinganya pengunaan analisis fundamental diantaranya dilakukan oleh Soepardi (2007), menyimpulkan bahwa Analisis fundamental berpengaruh sangat signifikan baik secara parsial maupun simultan terhadap harga saham "Perusahaan Batubara dan Perkebunan" dari CR, ROE, DER, EPS, hingga TATO. 
Selanjutnya, Anditya Soeroso (2013:1687-1696), bahwa analisis faktor fundamental pada resiko sistemmatis di pasar modal pada perusahaan food and beveragessangat berpengaruh dari CR, DER, TATO, hingga ROI secara simultan berpengaruh dan juga parsial terhadap resiko yang dihadapi oleh perusahan tersebut.

Menurut Surya dan Djawoto (2017:1-24), menyimpulkan perusahaan-perusahaan yang terdaftar di Jakarta Islamic Index (JII) pada priode 2008-2015 menguji analisis ekonomi yang diproksikan dengan iflasi dan tingkat suku bunga dengan currentratio, return on asset, debt to equity ratio, total asset turnover dan earning per share serta resiko sistematis terhadap return saham ternyata tidak berpengaruh secara signifikan.

Selanjutnya menurut, Winosa (2015) bahwa pengaruh analisis fundamental (current ratio, return on investment, book value per share, debt to equity ratio, dan net profit margin) terhadap harga saham. Sampel dalam penelitian ini adalah perusahaan yang terdaftar di Bursa Efek Indonesia menunjukkan bahwa secara bersama-sama variabel current ratio, return on investment, book value per share, debt to equity ratio, dan net profit margin berpengaruh signifikan terhadap Harga saham. Sehingga begitu pentingnya analisis fundamental dipengunakan untuk mengalasisi pergerakan dalam mengamati perkembangan satu efek atau lebih dalam pasar modal.

\section{Kesimpulan}

Berdasarkan hasil penelitian yang tersajikan diatas, dapat disampaikan bahwa investor dapat mengunakan analisis fundamental sebagai acuan dalam menentukan investasi yang dapat memaksimalkan profit dan meminimumkan resiko. Investor juga harus bisa lebih cermat dalam menganalisis pergerakan inflasi, suku bunga dan faktor eksternal yang lain dalam mengambil keputusan investasi dan memilih perusahaan yang memiliki struktur modal yang kuat sehingga dapat bertahan dalam mengahadapi resiko yang akan muncul. Selanjutnya, Perusahaan harus mampu mengelola investasi hingga dapat memunculkan potret keuangan yang tersajika dengan baik dalam neraca dan laporan keuangan. Tulisan ini hanya memberikan gambaran pentingya pengunaan analisis fundamental dalam mengambil keputusan untuk berinvestasi di "Bursa Efek". 


\section{DAFTAR PUSTAKA}

Anditya Soerosos.2013."Faktor Fundamental(Current Ratio, Total Debt To Equty Ratio, Total Asset Turn Over, Return On Investment) Terhadap Risiko Sistematis Pada Industri Food And Beverages di Bursa Efek Indonesia”.Jurnal EMBA.Vol.1(4).Hal 16871696.

Artha, Danika Reka,.Achsani, Noer Azam,.dan Sasongko,Hendro,.2014."Analisis Fundamental, Teknikal Dan Makroekonomi Harga saham Sektor Pertanian”.Jurnal Manajemen Dan Kewirausahaan.Vol.16(2).Hal:175-184.

Fajar Fuady.2014."Analisis Fundamental Saham Perusahaan Sektor Barang Konsumsi (Comsumer Goods) Di Indeks Saham Syariah Indonesia (ISSI)Periode 2011-2013 Dengan Metode Top Down Analisis".Skripsi UIN JAKARTA.Hal:16.

Hauwtan.Pegeen.2010."ANALISIS FUNDAMENTAL DAN TEKNIKAL SAHAM PT PP LONDON SUMATRA INDONESIA,TBK'. TESIS-UI. Hal:18-28 (diakses dari Internet 10/12/2017).

Indah Pertiwi.2014.“Analisis Pengaruh Return Jangka Pendek, Return Menengah, Return Jangka Panjang, Averege Weekly Turnover Dan Market Capitalization Dalam Memprediksi Return Saham Januari (Studi Empiris pada Saham Industri Manufaktur di Bursa Efek Indonesia Priode Tahun 2011-2014”. Artikel Program Studi Manajemen Universitas Diponogoro. Hal:2. Diakses 10/12/2017.

Laporan Perekonomian Bank Indonesia. 2016. "Bagian IV Tantangan, Arah Kebijakan, dan Prospek Perekonomian Indonesia”. Laporan Perekonomian Indonesia, Hal:227.

Nasution, Yenni Samri Juliati.2015."Peran Pasar Modal Dalam Perekonomian Negara".Jurnal Human Falah.Vol.2(1).Hal:95-112.

R.Agus Sartono.2010."Manajemen Keuangan Teori dan Aplikasi Edisi Ke 4".BPFEYOGYAKARTA.

Soepardi, Eddy Mulyadi., Dede Yusuf., Surahmat., dan Fera Koes Rahayu.2007."Perbandingan Analisis Fundamental Terhadap Harga Saham Perusahaan Batubara Dan Perkebunan Di Bursa Efek Indonesia”.Artikel (diakses 10/12/2017).

Surya, Fisa Tiana., dan Djawoto.2017."PENGARUH ANALISIS FUNDAMENTAL DAN RESIKO SISTEMATIS TERHADAP RETURN SAHAM PERUSAHAAN PRIODE 2008-2015'.Jurnal Ilmu dan Riset Manajemen.Hal:1-24.

Undang-Undang No.8 Tahun 1995 tentang Pasar Modal.

Winosa, Shilva Elwis.2015."Analisis Pengaruh Fundamental Keuangan Perusahaan Terhadap Harga Saham Perusahaan Yang Tercatat di Bursa Efek Indonesia”.'Naskah Publikasi Universitas Muhammadiyah Surakarta.Hal:1. 